Schmidt loved the country and the mountains as he loved his work and intercourse with his colleagues. He was a great meteorologist and a lovable man. His loss will be keenly felt by all who knew him personally and by many who knew him only through his published work. It is a blow which falls particularly severely on Vienna, the more so coming as it does after the sudden and unexpected death of Exner six years ago.

E. GOLD.

Prof. J. T. Cash, F.R.S.

JoHn Theodore CASH, emeritus professor of materia medica and therapeutics in the University of Aberdeen, who died on November 30, was a man of wide sympathies and, to those fortunate to know him intimately, a delightful companion. Born in Manchester in 1854, he studied arts and medicine at Edinburgh, qualified as M.B., C.M. in 1876, and proceeded to M.D., his thesis for which earned a gold medal, in 1879. After qualification he worked and studied at Paris, Vienna, Berlin and Leipzig.

Cash's early interests were in physiology and hygiene, but later they became almost purely pharmacological. The post-Continental period he spent in London, and investigated the pharmacological action of organic lead compounds, the action of chemical disinfectants (which he reported to the Local Government Board), and contributed, with Lauder Brunton, an important paper on the connexion between chemical constitution and physiological action to the Royal Society. He was elected a fellow of the Royal Society in $\mathbf{1 8 8 7 .}$

The appointment of Cash to the chair of materia medica and therapeutics at Aberdeen in 1886 was a surprise, for the chair had previously been held by medical practitioners, and Theodore Cash was a pure researcher. The appointment was, however, fully justified. Although only a part-time job, he devoted himself wholly to university work. A student of his first class was Arthur Cushny, who became successively professor of pharmacology in the University of Michigan, in University College, London, and lastly professor of materia medica and therapeutics in the University of Edinburgh.

At Aberdeen, Cash continued his investigations on chemical constitution and physiological action, then on the action of the pure organic nitrites prepared by Dunstan, and later on the action of the aconitines, which also had been prepared by Dunstan. The results were incorporated in papers to the Royal Society. They show that thoroughness and attention to detail which is characteristic of all Cash's work. He also investigated and wrote, among other matters, on tobacco smoking and skin irritants. His administrative work was equally thorough. For a time he was dean of the Faculty of Medicine and the University's representative on the General Medical Council. His work was acknowledged by the LL.D. of Edinburgh and, after retirement, of Aberdeen.

Cash was renowned as a fisherman as well as a pharmacologist. Once, the present writer when at a fisherman's inn in Scotland inquired from a visitor what fly he used and he replied "Cash's". On relating the incident to Prof. Cash, he confessed to having prepared and tried his own flies. This incident illustrates the man; he was as modest of his prowess with the rod as of his abilities in other spheres. $\mathrm{He}$ fished nearly all the streams of the British Isles, and up to a few years ago could still be found occasionally on the banks of his beloved Don.

Prof. Cash married the youngest daughter of the Right Hon. John Bright. Her death, soon after their removal to Hereford, was a great blow to him. There are four children of the marriage, two sons and two daughters, to whom we extend our sympathy.

C. R. M.

\section{Dr. G. Schack-Sommer}

Dr. Gustaf Schack-Sommer died in London on October 16, aged eighty-two years. The sugar industry, home-grown sugar in particular, and his many friends will regret the passing of one who was blessed with a charming personality and presence, and whose interest in sugar was maintained to the last. $\mathrm{He}$ was unmarried. It was his intention to be present at the International Conference of Sugar Analysts in London in September, but unfortunately he was prevented by ill-health at the last moment. His family home was at Marienlyst, Elsinore, in Denmark, but at the time of his birth in 1854 his father was Danish Consul in Hamburg, and it was there that he spent his school life, although the summer vacation was always spent at Elsinore. In 1872 he was attracted to Heidelberg by the work of Bunsen, Kirchhoff and Kopp, and in 1875 he graduated and obtained his Ph.D. degree. His first professional post was in a German chemical works.

In 1877 Dr. Schack-Sommer decided to live in England and took the opportunity offered him to assist at one of the first alkali works in this country, the Newcastle Chemical Works. In 1878 he left Newcastle for Liverpool, where he joined the sugarrefining firm of Crosfield, Barrow and Co., of which he became a partner in 1884. In the same year he renounced his Danish nationality in favour of English. In 1881 he assisted in the foundation of the Society of Chemical Industry; he became a fellow of the Institute of Chemistry a few years later.

Dr. Schack-Sommer's early years in Germany had impressed upon him the benefits resulting from the growing of sugar beets, and from 1889 until 1895 he was instrumental in the growing of sugar beet in Lancashire and Ireland. Each year the results were carefully tabulated, supporting his contention that the crop was as suitable for England as for the Continent. With other pioneers, of whom Lord Denbigh and Sir George Courthorpe were the chief, he never missed an opportunity either at lectures or meetings of impressing all concerned with the merits of beet growing in this country. In 1890 he delivered a lecture which was attended by many members of Parliament interested in agriculture, and he was one of the earliest members of the British Sugar Beet Council, becoming chairman of the Liverpool section in 1895. He frequently recalled the pleasure it had 